\title{
Polska na trasie chińskiego Jedwabnego Szlaku: szansa rozwojowa czy tylko wyzwanie?
}

\begin{abstract}
Idące do Europy dwa chińskie Jedwabne Szlaki, ogłoszone jesienią 2013 r., zaskoczyły nie tylko europejskie i światowe elity polityczne, lecz także środowiska akademickie. Ten bezprecedensowy projekt czy wizja chińskiego prezydenta Xi Jinpinga zwraca uwagę rozmachem i zasięgiem. Jest dowodem odrodzenia się Chin jako potęgi oraz ich globalnych ambicji. Celem tego opracowania jest pokazanie, jak do tego projektu odnoszą się kolejno elity państw Unii Europejskiej, regionu Europy Środkowo-Wschodniej, objętej inną chińska strategią 16+1 oraz w Polsce, która bezpośrednio na lądowym Szlaku się znalazła. Co z tą szansą Polska zrobiła? Z analizy wynika, że stosunkowo niewiele - mimo zauważalnej chińskiej obecności i interesów tu lokowanych. Jedwabne Szlaki pozostają więc dla Warszawy raczej niewykorzystaną, potencjalną szansą niż realną nową szansą rozwojową $i$ aby to zmienić, potrzebna jest polityczna wola, której po polskiej stronie brak.
\end{abstract}

Słowa kluczowe: Belt and Road Initiative - BRI, strategia 16+1, Chiny, Europa, geopolityka, strategie rozwojowe, nowy ład ekonomiczny.

\section{Wprowadzenie}

Ogłoszony przez prezydenta Xi Jinpinga, jesienią 2013 r., w dwóch turach projekt, a raczej geostrategiczna wizja, zwana w oryginale Yidai, yilu, przestawiana najpierw jako One Belt, One Road (OBOR), a następnie - BRI (Belt and Road Initiative), czyli Inicjatywa Pasa i Szlaku, w chwili pojawienia się wzbudziła konsternację nawet w samych Chinach, nie mówiąc o świecie zewnętrznym. Oto kraj dotychczas trzymający się podyktowanej w początkach lat 90. minionego stulecia, przez wizjonera reform Deng Xiaopinga, formuły taoguang, yanghui, a więc budowy potęgi po cichu, bez zwracania niczyjej uwagi, wystąpił z bezprecedensowym projektem, którego wcielenie w życie może zmienić układ sił na świecie.

W Chinach szybko przekuto ten pomysł na konkrety: we wszystkich ważniejszych ośrodkach akademickich kraju powołano zespoły, katedry, a nawet 
instytuty badawcze mające stanowić naukowe zaplecze BRI, z podstawowym zadaniem, by wypełnić tę koncepcję konkretną treścią. Na samym początku tej drogi było bowiem tylko pięć propozycji prezydenta Chin dla krajów, które do projektu chciałyby się włączyć: koordynacja polityk, lepsze połączenia komunikacyjne (drogowe i kolejowe), otwarty handel, wymiana finansowa oraz zacieśnianie współpracy na szczeblu najniższym, między obywatelami ${ }^{1}$.

Dość szybko chińskie środowisko naukowe i tamtejsi eksperci pokazali, że chodzi tu o coś znacznie większego - by pokazać Chiny jako nowego geostrategicznego gracza, korzystającego ze swojego szybko rosnącego potencjału gospodarczego i finansowego, powracającego do statusu supermocarstwa oraz wielkiego ośrodka siły i pomysłów, jaki Chiny już kiedyś przez wieki posiadały (Maddison, 2007). A niektórzy przyznali nawet, że przy kreowaniu tej koncepcji Chiny sięgnęły do pomysłów „ojców geostrategii”, czyli Halforda Johna Mackindera i Nicholasa Spykmana, mówiących o łączącym Europę i Azję heartlandzie oraz otaczającym go łańcuchu mórz i oceanów, czyli rimlandzie (Xin Zhang, 2016, s. 28; szerzej na ten temat: Bartosiak, 2016. s. 70, 71). Cechą wyróżniającą tę koncepcję jest bowiem to, że oba Jedwabne Szlaki - lądowy i morski - zmierzają w kierunku zachodnim, przede wszystkim do Europy (choć z odnogami na Bliski Wschód i do Afryki, a z czasem okazało się, że niektóre projekty zainicjowano nawet w Tajlandii czy Indonezji).

Koncepcję OBOR, a potem BRI (chińska nazwa pozostała ta sama) przyjęto $\mathrm{w}$ świecie zewnętrznym, a przede wszystkim na szeroko rozumianym Zachodzie nie tylko z zaskoczeniem, lecz także z mieszanymi uczuciami. Owszem, pojawily się opinie, zgodnie z którymi BRI to „najbardziej znacząca i dalekosiężna inicjatywa, jaką Chiny kiedykolwiek przedstawiły" (Winter, 2016). Jednakże znacznie częściej stawiano tezy mówiące o tym, że oto na scenę światową wszedł nowy gracz wagi najcięższej, co naturalnie największą konsternację wzbudziło w USA, u dotychczasowego hegemona na scenie światowej.

Doskonałym dowodem na tę tezę jest książka Michaela Pillsbury'ego, który całe życie spędził w amerykańskim środowisku wywiadowczo-analitycznym zajmującym się Chinami. Po ogłoszeniu koncepcji OBOR wydał on tom o znamiennym tytule „Stuletni maraton”, w którym nawiązał do jeszcze innej, strategicznej koncepcji Xi Jinpinga, mówiącej o „dwóch celach na stulecie”. Pierwszy, na stulecie rządzącej Komunistycznej Partii Chin (KPCh), do realizacji zaś w połowie 2021 r., to zmiana tamtejszego modelu gospodarczego i oparcie go nie na eksporcie, jak było dotychczas, lecz na silnej i kwitnącej klasie średniej

1 Lądowy Jedwabny Szlak został ogłoszony 7 września 2013 r. w Astanie, natomiast morski Jedwabny Szlak ogłoszono 3 października 2013 r. na Bali w Indonezji (zob. Xi Jinping, 2014, s. 315,320$)$. 
oraz dynamicznym rynku wewnętrznym. Drugi „cel na stulecie”, czyli okragłą setną rocznicę proklamowania Chińskiej Republiki Ludowej (ChRL), a więc do wypełnienia na 1 października 2049 r., to nic innego, jak „wielki renesans chińskiego narodu", co wymaga spełnienia wielu poważnych wymagań, w tym kluczowego - pokojowego zjednoczenia z Tajwanem, bo przecież mamy do czynienia $\mathrm{z}$ dwoma organizmami z Chinami w nazwie 2 .

Zdaniem Pilsbury'ego i wielu innych ekspertów, te „dwa cele na stulecie”, połączone z BRI, to nic innego, jak wyłonienie się nowego geostrategicznego gracza, a zarazem najpotężniejszego rywala USA do pierwszoplanowej roli na globie. Przez dziesięciolecia, począwszy od wizyt Henry'ego Kissingera i prezydenta Richarda Nixona w ChRL w początkach lat 70. minionego stulecia, USA mocno się przyczyniały do tej sytuacji, co Pillsbury uznał zresztą za „bodaj najbardziej systematyczną, znaczącą i groźną porażkę wywiadu w amerykańskiej historii" (Pillsbury, 2016, s. 16).

\section{Percepcja BRI}

\subsection{W Unii Europejskiej (UE)}

Problemem jest, że chińskie Jedwabne Szlaki dość jednoznacznie pokazują nowego pretendenta do hegemonii na światowej scenie, co musi budzić zrozumiałą konsternację dotychczasowego hegemona, czyli USA. Narodziła się bowiem tym samym sytuacja nazwana przez ekspertów Uniwersytetu Harvarda „pułapką Tukidydesa”, kiedy to interesy dotychczasowego hegemona zderzają się z interesami pretendenta, co prowadzi najczęściej do wojny, niekoniecznie tylko handlowej. Podobnie dzieje się i teraz, szczególnie na Morzu Południowochińskim, kontrolowanym dotychczas przez flotę amerykańską, ale przy brzegach którego, w porcie Xiamen i paru innych miejscach rusza Morski Jedwabny Szlak, co zmusza Chińczyków do zwiększenia swej obecności, także militarnej, na tym akwenie. To obszar, gdzie „pułapka Tukidydesa” jest otwarcie zastawiona, a ścieranie się wpływów i interesów USA i ChRL zarówno tutaj, jak i na całej arenie międzynarodowej wydaje się być już nieuniknione³

2 O nowym modelu: Góralczyk, 2017, s. 220-235. O nowej strategii: Góralczyk, 2018.

3 Pomysł pochodzi od emerytowanego i doświadczonego badacza i administratora z Harvardu, Grahama Allisona, który - wraz z zespołem - zbadał pod tym kątem okres od roku 1500 do współczesności. Badania wykazały, że „pułapek” było w tym czasie 16, z których 12 zakończyło się wojną (zob. Allison, 2017). W literaturze polskiej zob. Bartosiak, 2016, s. 554-663. 
Początki prawdziwej wojny handlowej, zainicjowanej wiosną 2018 r. przez administrację prezydenta Donalda Trumpa, stawiającego na hasło America First i w istocie izolacjonizm w handlu ${ }^{4}$, napotyka chińskie retorsje i zderza się z proponowaną i forsowaną przez władze ChRL polityką wolnego handlu, bez przeszkód i zahamowań, co tak silnie zaznaczył Xi Jinping w dwóch swoich głośnych wystąpieniach: na Forum Ekonomicznym w Davos w styczniu 2017 r. oraz na podobnym Forum w Boao w kwietniu 2018 roku (Xinhua, 2017; Xi Jinping, 2018).

OBOR, a następnie BRI przyjęte zostały z mieszanymi uczuciami również w UE i jej instytucjach, jak też zróżnicowały podejście do nich ze strony państw członkowskich w UE. W dostępnych już dzisiaj analizach ${ }^{5}$ wskazuje się, owszem, na nowe szanse i możliwości, idące w ślad za chińskimi koncepcjami i ich nową obecnością na terenie Europy, dotychczas nieznaną ani co do skali, ani - kapitałowego i inwestycyjnego - zaangażowania. Jeszcze częściej podkreśla się jednak, a w miarę upływu czasu argumenty te narastają i nabierają większej mocy, że chińska wizja ma poważne niedostatki i mankamenty takie przykładowo, jak: brak precyzji w przestawianych mapach i trasach BRI, forsowanie interesów własnych firm, brak przejrzystości proponowanych umów, sprzeczności proponowanych umów ze standardami i normami obowiązującymi w UE, niejasności dotyczące finansowania oraz publicznych przetargów dotyczących poszczególnych projektów, kwestie przestrzegania praw własności, zbyt duży nacisk kładziony na porozumienia dwustronne, z poszczególnymi państwami członkowskimi UE, które niemalże bez wyjątku cierpią na chroniczny deficyt handlowy z ChRL, czasami wyjątkowo wysoki, co prowadzi z jednej strony do ,asymetrii wpływów i oddziaływania”, a drugiej grozi realizacją przez Chiny strategii „dziel i rządź" wśród państw członkowskich. Te opinie i zarzuty znalazły nawet dyplomatyczne odzwierciedlenie, kiedy to w kwietniu 2018 r. ambasadorzy państw UE w Pekinie, z wyjątkiem przedstawiciela Węgier, sformułowali na piśmie te zarzuty, począwszy od najpoważniejszego - że implementacja BRI grozi rozbiciem UE6.

Podstawowym mankamentem UE w stosunkach z Chinami - i ogólnie, „wschodzącymi rynkami” - jest brak spójnej i jednolitej strategii wobec nich, co tym bardziej prowadzi do asymetrii w świetle śmiałych wizji w ramach BRI.

4 Wstępne analizy: https://www.project-syndicate.org/bigpicture/trump-s-trade-war-expands (dostęp: 16.07.2018).

5 Dwie najlepsze i najbardziej wnikliwe, to: Godemont i. Vasselier, 2017; MERICS i Rhodium Group, 2017.

6 https://global.handelsblatt.com/politics/eu-ambassadors-beijing-china-silk-road-912258 (dostęp: 20.07.2018). 
Trzeba tak niestety stwierdzić, mimo przyjęcia przez Komisję Europejską w listopadzie 2013 r. strategicznej agendy współpracy w stosunkach dwustronnych z Chinami na okres do roku 2020 i umieszczenia w niej aż 94 „kluczowych inicjatyw" (EEAS, 2016) dotyczących tej współpracy w sferze nie tylko gospodarczej czy handlu, lecz także przykładowo w dziedzinie bezpieczeństwa i pokoju, w zakresie zrównoważonego rozwoju, współpracy naukowej i naukowo-badawczej czy turystyki i wymiany osobowej.

Drugi czynnik, który ujawnił się dosyć szybko po ogłoszeniu chińskiej Inicjatywy, to narastająca błyskawicznie chińska obecność inwestycyjna na terenie UE, która w roku 2016 sięgnęła 35 mld euro (skok aż o 77\% w stosunku do roku poprzedniego), podczas gdy unijna na terenie ChRL sięgnęła tylko 7,6 mld euro $^{7}$. Co należy bowiem podkreślić i wyeksponować - już w rok po ogłoszeniu wizji OBOR chińskie inwestycje poza granicami kraju przewyższyły te do Chin przychodzące, które przynajmniej od 1992 r., czyli otwarcia Chin na globalizację po rozpadzie ZSRR, zawsze były wysokie. Tę zmianę trzeba uznać za przewrót iście kopernikański, a zrazem tutaj szukać wyjaśnienia, czemu prezydent Xi Jinping ze swą wizją BRI wyszedł - po prostu Chiny zaczynają mieć nadwyżki kapitałowe i inwestycyjne moce, które są i będą w stanie należycie spożytkować nie tylko u siebie, ale także na obcych rynkach.

I wreszcie trzeci, newralgiczny element: jak się szybko okazało, strona chińska nie tyle przychodzi do Europy i UE z nowymi inwestycjami typu greenefield, a więc pomysłami budowy nowych obiektów od samych fundamentów, lecz także jest zainteresowana operacjami typu fuzje i przejęcia, a raczej przede wszystkim przejęcia, najczęściej zresztą firm czy marek specjalizujących się w nowoczesnych i najnowszych technologiach. To właśnie przejęcie szwajcarskiego molocha chemicznego Syngenta za sumę szacowną na 65 mld dolarów, a następnie niemieckiej firmy Kuka, specjalizującej się w produkcji robotów przemysłowych (za sumę szacowaną na 5,5 mld euro) sprawiło, iż wszystkie państwa europejskie, w tym Niemcy, najbardziej zaangażowane we współpracę z Chinami, ostatecznie przekonały się, iż mają do czynienia z zupełnie nową chińską obecnością u siebie, w ramach której przejmowane są „najlepsze srebra rodowe”, jak to publicystycznie ujmowano. W efekcie nawet ówczesny niemiecki minister spraw zagranicznych Sigmar Gabriel zaczął zachęcać do ścisłej współpracy państw członkowskich UE i wypracowania przez nie wspólnej strategii w kontaktach z Chinami, albowiem - jak mówił - ,jeśli nie uda się nam wypracować wspólnej strategii wobec Chin, to wtedy Chinom uda się podzielić Europę" (Godemont i Vasselier, 2017, s. 17).

7 A wszystko to przy ujemnym bilansie handlowym UE w tym samym roku rzędu 174 mld euro (zob. Godemont i Vasselier, 2017, s. 37). 
Dopiero przejęcia nowoczesnych firm oraz wysoka obecność inwestycyjna Chin na kontynencie europejskim do pewnego stopnia „obudziła” instytucje unijne oraz władze poszczególnych państw członkowskich. Wreszcie uświadomiono sobie, iż pomysł BRI rzeczywiście zaczyna być realizowany i nie może być $\mathrm{w}$ żadnej mierze ignorowany, jak to było na samym początku tuż po jego ogłoszeniu. Jego implementacja tworzy bowiem w stosunkach wzajemnych UE z ChRL zupełnie nową jakość, wymagającą od państw unijnych nowego namysłu, zastanowienia i prawdziwej strategii w tych zupełnie nowych okolicznościach.

Równocześnie jednak, co raczej zrozumiałe, władze unijne są ostrożne w przyjmowaniu chińskich sugestii, by „łączyć siły” w celu przeciwstawienia się inicjatywom administracji amerykańskiej Donalda Trumpa zmierzającym do ograniczeń w handlu. UE też na tych amerykańskich pomysłach traci, ale dość wyraźnie podkreśla, iż USA pozostają jej kluczowym, strategicznym partnerem. Innymi słowy, nawet groźba wojny handlowej nie oznacza jeszcze zmiany sojuszy czy nowej konfiguracji na scenie globalnej ${ }^{8}$. Tym samym UE mimo wszystko nie stawia na Chiny. A co na to państwa regionu EŚW?

\subsection{Percepcja BRI w regionie Europy Środkowej i Wschodniej (EŚW)}

Specyfika stosunków państw regionu EŚW z Chinami polega na tym, że państwa te rozpoczęły, też z inicjatywy Chin, wzmocnioną współpracę z ChRL jeszcze przed ogłoszeniem wizji BRI. Jeszcze poprzedni premier Wen Jiabao ogłosił bowiem w Warszawie w kwietniu 2012 r. koncepcję współpracy w ramach, wymyślonej w Pekinie, formuły 16+1, czyli Chin z 16 państwami naszego regionu (czterema z Grupy Wyszehradzkiej, trzema Bałtyckimi oraz państwami bałkańskimi, z Rumunia, Bułgarią i Albanią oraz pojugosławiańskimi, bez Kosowa). Taki a nie inny skład 16 dowodzi, że Chiny nie za bardzo zważają ani na granice UE (11 członków, 5 kandydatów), ani - tym bardziej - strefy euro. Bardziej przekonująca dla nich była - i jest - bliskość geograficzna tych państw w słabo dotychczas rozpoznanym, a ważnym regionie u bram silnej Europy Zachodniej, jak też jego nieco zróżnicowane, ale wspólne doświadczenie „realnego socjalizmu" czy gospodarki planowej.

Pierwotnie strona chińska zaproponowała w ramach tej współpracy wizję „12 przedsięwzięć” czy kroków i wyasygnowała na te cele sumę 10 mld dolarów. Niewiele z tych planów udało się zrealizować, a niejako „okręt flagowy” tej współpracy, czyli szybka kolej łącząca Budapeszt z Belgradem (docelowo cho-

8 "We don't agree with Trump, but that doesn't mean we want to gang up on America with China, says EU adviser ahead of summit". Pozyskano z: https://www.project-syndicate.org/ bigpicture/trump-s-trade-war-expands (dostęp: 16.07.2018). 
dziłoby o połączenie portu w Pireusie, znajdującego się w rękach chińskiej firmy Cosco i wieńczącego, jak dotąd, Morski Jedwabny Szlak z Łodzią, czyli ważnym w chińskich planach komunikacyjnym centrum na drodze lądowego Jedwabnego Szlaku), nie jest realizowana do dziś, z racji oporu - i zarzutów - Komisji Europejskiej o „brak transparentności” (szerzej: Góralczyk, 2017, s. 153-162).

Dostrzegając problemy w ramach tej współpracy, jak też niechęć do niej otwarcie wyrażaną w instytucjach unijnych oraz najważniejszych stolicach państw członkowskich UE, począwszy od Berlina, strona chińska na szczycie $16+1$ w listopadzie 2016 r. Rydze, ustami szefa jej delegacji, premiera Li Keqianga, wyszła z kolejną, pięciopunktową propozycją współpracy. Zakładała ona: stymulowanie handlu, przyspieszenie budowy połączeń komunikacyjnych (zarówno infrastruktura, jak i logistyka), budowę chińskich parków przemysłowo-technologicznych w państwach 16 (jeden z nich powstał już poza nią, w Mińsku białoruskim), ożywienie współpracy finansowej (Węgierski Bank Narodowy jest zaangażowany $\mathrm{w}$ projekty badawcze nad umiędzynarodowieniem juana) oraz zwiększenie wymiany turystycznej i osobowej (Oehler-Sincai, 2018, s. 8).

Ta częściowa zmiana priorytetów niewiele jak dotychczas zmieniła: Chiny najwyraźniej nadal nie są zadowolone z tej współpracy. Choć początkowe założenia były inne i skoncentrowane na gospodarce oraz handlu, nadal poziom współpracy politycznej wyprzedza poziom wymiany gospodarczej. Albowiem jedynym wymiernym dotychczasowym osiagnnięciem w ramach inicjatywy $16+1$ jest powołanie jej Sekretariatu z siedzibą w Pekinie ${ }^{9}$ oraz doroczne szczyty, z których ostatni odbył się w Sofii w lipcu 2018 roku$^{10}$. Strona chińska zdaje się jednak coraz bardziej zmierzać do koncepcji przedstawionej przez prezydenta Xi Jinpinga wobec uczestników szczytu w Suzhou (listopad 2015), by „w pełni zintegrować" koncepcję 16+1 z BRI (Joić, 2017, s. 2). Pojawiają się również pomysły, by szczyty $16+1$ odbywały się nie - jak dotąd - corocznie, lecz raz na dwa lata, co dla wielu obserwatorów jest dowodem, iż projekt jednak nie za bardzo chwycił.

Natomiast przed ostatnim szczytem w Bułgarii głośno było o zaproszeniu nań także Niemiec. Jest to pomysł od pewnego czasu forsowany przez chińskich specjalistów zajmujących się Niemcami, którzy jednoznacznie traktują cały obszar EŚW jako niemiecką strefę oddziaływania w wymiarze politycznym i gospo-

9 Powstał też odrębny, koordynowany przez Polskę, sekretariat koordynujący współpracę logistyczną.

10 Uzupełnia je cała sieć innych spotkań i konwentykli: organizowane cztery razy do roku spotkania ambasadorów państw $16 \mathrm{w}$ Pekinie, organizowane raz na pół roku (raz w Pekinie, raz w państwie organizującym doroczny szczyt) spotkania Narodowych Koordynatorów projektu, uzupełnione o spotkania think tanków i ekspertów. 
darczym. Dlatego też, jak sugerują, włączenie do ram $16+1$ Niemiec byłoby najlepszym sposobem na odsunięcie ich wyraziście formułowanych podejrzeń dotyczących prawdziwych motywów Chin w zaangażowaniu na tym obszarze (Zou Lu 2018, s. 8, 9).

Jest jeszcze inny, ważny element dowodzący nowej dynamiki wydarzeń wokół tego pomysłu, czyli nowy czynnik o charakterze geostrategicznym, jakim jest niekonwencjonalne zachowanie administracji i samego prezydenta Donalda Trumpa, tak w stosunkach z Chinami i regionie Azji i Pacyfiku, jak i transatlantyckich w ramach NATO oraz relacjach dwustronnych USA - UE. W tym właśnie kontekście strona chińska poszukuje nowych rozwiązań, czego dowodem wizyta szefa delegacji chińskiej, premiera Li Keqianga na szczycie w Sofii, bezpośrednio po nim w Berlinie, gdzie m.in. zapadła bezprecedensowa decyzja by niemiecki konglomerat BASF wybudował własną inwestycję o wartości rzędu 10 mld dolarów na południu Chin, bez udziału chińskiego kapitału, co jest rozwiązaniem zupełnie nowym i dotychczas na terenie ChRL nie stosowanym ${ }^{11}$.

Innym wartościowym osiągnięciem współpracy w ramach $16+1$ jest powołanie w kwietniu 2017 r. w Budapeszcie Instytutu Chiny - EŚW (China - CEE Institute) przez Chińską Akademię Nauk Społecznych (Chinese Academy of Social Science - CASS) w Pekinie, najpoważniejszy chiński think tank pracujący na rzecz władz, pierwszy w ogóle tego typu instytut badawczy poza Chinami. Na jego czele stanęli szefowie Instytutu Europy w CASS, którzy już wcześniej wykazali się największym zasięgiem badań nad $16+1$ oraz BRI (wraz z cenną serią wydawniczą) ${ }^{12}$ i są najcenniejszą pod tym względem placówką badawczą obok specjalnego Instytutu Badań nad Jedwabnym Szlakiem (China Silk Road Institute), powołanym w Pekinie przed pierwszym szczytem BRI (odtąd ma być organizowany co dwa lata). Instytut w Budapeszcie opublikował już dwie wartościowe serie working papers nt. wspólpracy w ramach inicjatyw $16+1$ oraz BRI. Planowane są następne wydarzenia i publikacje, w tym książkowe ${ }^{13}$.

$\mathrm{Z}$ dostępnego dotychczas stanu badań wynika, że:

- państwa regionu EŚW, podobnie jak państwa całej UE, są dość mocno podzielone w stosunku do chińskich inicjatyw. Najbardziej pozytywnie odnoszą się do nich Węgry, Czechy i Rumunia oraz - ostatnio - obszar Zachod-

11 https:/cen.acs.org/business/petrochemicals/BASF-considering-10-billion-investment/96/ web/2018/07 (dostęp: 16.07.2018).

12 Trzy najcenniejsze jak dotąd prace, to: Liu Zuokui, 2017; Huang Ping i Liu Zuokui, 2017; Chen Xin, 2017.

13 W pierwszej transzy, opublikowanej w listopadzie 2017 r., było to kilkanaście opracowań, w drugiej, opublikowanej w czerwcu 2018 - ponad dwadzieścia. Są one dostępne na stronie: www.china-cee.eu i stanowią ważny materiał wykorzystany także w tym opracowaniu. 
nich Bałkanów, tzn. państw pojugosławiańskich, z wiodącą rolą pod tym względem Serbii. Natomiast bardziej wstrzemięźliwe są Polska, Państwa Bałtyckie, Albania czy Słowacja;

- znajdująca się w centrum w chińskich propozycji i zainteresowań współpraca inwestycyjna nie przynosi, jak dotąd, spodziewanych efektów, a chińskie inwestycje zmierzające do Europy są umieszczane przede wszystkim w Niemczech, Wielkiej Brytanii, Francji i Włoszech. Ostatnio, od roku 2017 widać też pewną nową dynamikę pod tym względem na terenie Zachodnich Bałkanów (zakłady metalurgiczne Smederevo, termy w Kostolac i pierwsza w kraju elektrownia wiatrowa w Serbii, fabryka samochodów elektrycznych Rimac i renowacja uzdrowiska Krapinske Toplice oraz most na półwyspie Pelješac w Chorwacji, inicjatywa „pięciu portów” obejmujących włoskie porty Triest, Wenecję, Ravennę, słoweński Koper i chorwacką Rijekę). Przy czym wszystkie badania i dane świadczą, że bezwzględnie pierwszym partnerem Chin na terenie Zachodnich Bałkanów jest Serbia, drugi kraj w ramach 16, obok Węgier, mający wyraźną wolę polityczną by tę współpracę rozwijać, co tym bardziej kontrastuje z odczuwalnym w regionie, w tym w Polsce, rozczarowaniem stanem dotychczasowej współpracy;

- jeśli chodzi o dotychczasowe chińskie inwestycje w regionie EŚW, to nadal rolę wiodącą odgrywają tu jednak państwa wyszehradzkie, w tym Czechy (34\% całości 16, gdzie chińskie firmy przejęły tamtejsze linie lotnicze, klub sportowy Sparta Praha, dwa luksusowe hotele w centrum Pragi, a negocjowane jest przejęcie wielkiego browaru), Węgry (19\%, głównie przejęcie konglomeratu chemicznego Borsodchem przez spółkę Wanhua) oraz Polska (9\%) (Lin Yue, 2018, s. 12, 13).

- tylko Węgry w regionie mają wyraźną, prowadzoną od 2011 roku strategię wobec Chin i partnerów na Wschodzie, zwaną keleti nyitás (otwarcie na wschód), która jednakże nie przyniosła, jak dotąd, spodziewanych efektów, chociaż politycznie mocno zbliżyła oba kraje. Dostępne badania pokazują też, że to Węgry są na czele listy państw 16 , w których organizowanych jest najwięcej imprez i wspólnych przedsięwzięć z Chinami;

- dotychczasowe doświadczenie współpracy w ramach $16+1$ dowodzi, iż przebiega ona niemal wyłącznie na zasadzie porozumień dwustronnych poszczególnych państw 16 z Chinami i nie przyniosła żadnej nowej jakości we współpracy regionalnej (niezrealizowany projekt szybiej kolei łączącej Budapeszt z Belgradem, projekt „pięciu portów” jedynie na papierze itp.). Co więcej, w wielu krajach 16 konterwersje budzą też chińskie warunki kredytowania proponowanych inwestycji, w tym znacznego udziału ich przedstawicieli i firm na budowach. To samo dzieje się zresztą po stronie unijnej, 
która wyszła nawet ostatnio z porpozycją screeningu, a więc uważnego monitorowania chińskich kontraktów i inwestycji na jej obszarze.

\subsection{Percepcja BRI w Polsce}

Ani koncepcja 16+1, chociaż narodzona i ogłoszona w Polsce, ani idącą w ślad za nią, już nie regionalna lecz globalna w swym wymiarze, BRI nie znalazły się w centrum zainteresowania polskiej polityki zagranicznej (Stanzel, Kratz, Szczudlik i Pavlićević, 2016). Jest to wyraźny mankament, ponieważ, zdaniem autora niniejszego opracowania, po raz pierwszy w długich chińskich dziejach (nie licząc krótkiego epizodu jesienią 1956 r., gdy władze w Pekinie stanęły po stronie Władysława Gomułki) w interesie Chin leży rozwój współpracy z Polską. A to $\mathrm{z}$ tego powodu, że Polska znalazła się na głównej osi lądowego Jedwabnego Szlaku prowadzącego z Chin centralnych, przez Xinjiang, Kazachstan, Rosje i Białoruś, aż do Europy Zachodniej (Amsterdamu, Rotterdamu czy Hamburga).

Polska posiada niezbywalny atut w stosunkach z nabierającymi globalnego rozmachu Chinami w postaci swego miejsca na mapie. To, co było naszym prawdziwym przekleństwem przez wieki, położenie między Rosją a Niemcami, z chłodnego oglądu Chin jest najlepszym możliwym atutem geostrategicznym. Warto byłoby go należycie wykorzystać, ale - jak dotąd - udało się nam osiągnąć sukcesy jedynie w sferze politycznej, a znacznie mniej w gospodarczej, choć z założenia powinno być odwrotnie.

Na stosunkach demokratycznej Polski z Chinami na dość długo zaciążyła jedna data - 4 czerwca 1989 roku - gdy w Chinach doszło do siłowego rozwiązania głębokiego kryzysu na placu Tiananmen, a w Polsce w tym samym dniu doszło do pierwszych, ograniczonych, ale częściowo demokratycznych wyborów, które już we wrześniu tego roku przyniosły pierwszy demokratyczny rząd w państwach byłego bloku wschodniego, czyli gabinet premiera Tadeusza Mazowieckiego. Data ta stała się niejako „kamieniem węgielnym” stosunków dwustronnych, mocno je - ideologicznie - obciążając, mimo że Chiny podchodzą do współpracy z innymi państwami pragmatycznie, a nie ideologicznie (Góralczyk, 2009, s. 399). Przez następne dwie dekady, co najmniej do wielkiego kryzysu na światowych (czytaj: zachodnich) rynkach, podejście demokratycznej Polski do autorytarnych Chin było przesycone swego rodzaju mesjanizmem czy poczuciem wyższości (nowej demokracji nad autokratycznym - i przebrzmiałym - „realnym socjalizmem”).

Sytuacja zmieniła się dopiero na przełomie pierwszej i drugiej dekady XXI wieku, częściowo z racji kryzysu 2008 r., a chyba jeszcze w większym stopniu z powodu powolnego uświadamiania sobie przez cały Zachód szybko rosną- 
cej roli ChRL jako gospodarczego i handlowego giganta. Politycznym przełomem okazała się wizyta w Chinach prezydenta Bronisława Komorowskiego pod koniec 2011 r., kiedy podpisano porozumienia i podniesiono wzajemne relacje do poziomu strategicznych. Natomiast w trakcie wizyty prezydenta Xi Jinpinga w Polsce w czerwcu 2016 r. podniesiono stosunki dwustronne do poziomu najwyższego z możliwych: rozwiniętego partnerstwa strategicznego (comprehensive strategic partnership) (Xinhua, 2016). Wysoki poziom dialogu politycznego na najwyższym szczeblu podtrzymały: wizyta prezydenta Andrzeja Dudy na szczycie w 16+1 w Suzhou (choć organizowana na szczeblu premierów, strona polska, wykorzystując czas zmiany własnej administracji, wysłała tam prezydenta, na co strona chińska odpowiedziała - organizacją ad hoc wizyty oficjalnej polskiego prezydenta, dowodząc wagi przykładanej do wzajemnych relacji) oraz udział polskiej premier Beaty Szydło na pierwszym szczycie BRI w Pekinie w maju 2017 roku.

Niestety, towarzyszące tym wizytom porozumienia (zresztą, nie zawsze tak było), w tym blisko 40 podpisanych podczas wizyty chińskiej głowy państwa w RP albo nie zostały zrealizowane, albo były mocno spowalniane. Do rangi symbolu urosła decyzja szefa polskiego MON, by nie udzielić stronie chińskiej zgody na zakup działki należącej do Agencji Mienia Wojskowego, na której strona chińska zamierzała pobudować - kluczowe w swoich planach - centrum komunikacyjne na lądowym Jedwabnym Szlaku.

Rozwiązanie, jakie zastosowano w efekcie tej polskiej decyzji, czyli podpisanie porozumień na szczeblu samorządowym i przeniesienie chińskiego transportu kolejowego z Łodzi do pobliskiego Kutna dowodzi jednak, po pierwsze, skuteczności i determinacji strony chińskiej, a także, po drugie, jej dużego pragmatyzmu. Polska jest w chińskich planach ważnym ogniwem tak w ramach $16+1$, jak i BRI i ma nim pozostać. W efekcie, mamy do czynienia $\mathrm{z}$ wieloma chińskimi przedsięwzięciami na terenie RP, najczęściej o charakterze lokalnym, w wyniku porozumień z tamtejszymi władzami.

Na plan pierwszy należy wysunąć kwestię połączeń kolejowych. Albowiem akurat pod tym względem Polska odgrywa rolę nie tylko centralną, lecz wręcz pionierską w regionie. A to dlatego, że jeszcze przed ogłoszeniem inicjatyw $16+1$ oraz BRI ulokowana w Lodzi firma Hatrans wyszła z propozycją wykorzystania połączeń kolejowych dla rozwoju kontaktów handlowych z Chinami. Pierwsze składy pociągów z Chengdu w prowincji Sichuan przybyły, po blisko dwutygodniowej podróży do Łodzi 2 stycznia 2013 roku. Połączenia w obu kierunkach zainicjowano w maju tegoż roku, uzupełniając inne głośne i ważne połączenie z Chinami na linii Chongqing - Duisburg, otwarte w roku 2011. Regularne połączenia składów towarowych na tej trasie rozpoczęto w roku 
2015. Przy czym w początkowej fazie towary szły niemal wyłącznie w jednym kierunku - z Chin do Polski (Czerep, 2017; szerzej i wnikliwiej na ten temat: Jakóbowski, Popławski i Kaczmarski, 2018, s. 1, 12). Dopiero po roku 2015 sytuacja zaczęła się nieco zmieniać i również składy zmierzające do Chin, zarówno z Lodzi, jak i z Kutna, zaczęly być załadowywane przede wszystkim towarami rolnymi, jak owoce (głównie jabłka) czy przetworzone warzywa, a z czasem też towary chemiczne i przemysłowe. Ocenia się, że na koniec roku 2017 do Łodzi i Kutna przybywało ok. $25 \%$ całości towarów trafiających drogą kolejową do UE, a tymczasem dynamika obrotów kolejowych między Chinami a UE wzrosła w minionej dekadzie stukrotnie.

Jeszcze przed inauguracją połączeń kolejowych, co też trudno uznać za prawdziwy przypadek, już w 2009 r. chińska firma Covec wygrała przetarg na budowę odcinka autostrady pomiędzy Łodzią a Warszawą, co było pierwszym tego typu eksperymentem w wykonaniu chińskiej kompanii na terenie UE. Przedsięwzięcie to nie zakończyło się jednak sukcesem, Covec zmuszony był najpierw z polskiego rynku się wycofać, a następnie zapłacić odszkodowanie. Okazało się, że zderzyły się ze sobą odmienne mentalności biznesowe: Chińczycy zawierzyli porozumieniom i zapewnieniom politycznym na wysokim szczeblu, uznając tym samym, że posiadają należyte guanxi, a więc powiązania z należytymi czynnikami i osobami i nie dokonali właściwego rozeznania rynku (weszli bez feasibility study), a następnie zderzyli się z wymogami unijnymi i wolno napływającymi pieniędzmi, co wznieciło bunt polskich podwykonawców dla Covec. Innymi słowy, chińska mentalność oparta na osobistych relacjach i powiązaniach zderzyła się z unijnym porządkiem biurokratycznym i instytucjonalnym: u nich liczą się osoby i stanowiska, u nas (czytaj: w UE) instytucje, reguły i regulacje prawne.

Klęska Covec jednak Chin nie zniechęciła. Wręcz przeciwnie, jeszcze zwiększyły one swoją obecność w Polsce i w regionie, traktując przypadek tej firmy jako wypadek przy pracy, a zarazem cenne doświadczenie na trudnym i wymagającym rynku unijnym.

\section{Korzyści i ryzyka związane z BRI}

\subsection{Potencjalne korzyści}

Drugim obszarem, obok połączeń kolejowych i perspektywy wykorzystania szybkich chińskich kolei do połączeń w regionie (Budapeszt - Belgrad) są pierwsze kontrakty na chińskie inwestycje w sektorze energetycznym na 
obszarze EŚW. Największy i najbardziej zaawansowany pośród nich jest blok energetyczny w elektrowni Cernavoda II na terenie Rumunii, którego kontrakt opiewa na 7 mld euro i ma być sfinalizowany już w roku 2019. Inne podpisane porozumienia dotyczą elektrowni atomowych Temelin - Dukovany w Czechach (ok. 15 mld euro, ale do uruchomienia dopiero w trzeciej dekadzie tego stulecia) oraz Belene w Bułgarii. W tym kontekście zwracają uwagę również pierwsze chińskie projekty i inwestycje na terenie Polski, realizowane na szczeblu lokalnym, jak budowa trakcji elektrycznych w okolicach Słupska, Szczecina, Chełma i Lublina przez chińskie konglomeraty China State Grid (dwa pierwsze) oraz Sinohydro (dwa pozostałe).

Do dwóch wcześniejszych inwestycji, a raczej przejęć - w hucie Stalowa Wola przez firmę Liugong oraz Fabryki Łożysk Tocznych w Kraśniku przez Tri Gong - w ostatnich latach doszły takie przejęcia, jak przez China Everbright Intl. firmy Novago w Mławie specjalizującej w utylizacji odpadów czy firm Hongbo pod Opolem (oświetlenie led), Nuctech w Kobyłce (osprzęt na lotniskach), a także budowa montowni telewizorów TCL pod Żyrardowem, składalni rowerów w Koszalinie (Athletic Group) czy produkcja świec pod Tarnowem (Dalian Talent) (Sarek, 2017, s. 70-73).

Jak widać i co można udowodnić, chińska obecność gospodarcza i inwestycyjna w Polsce stale rośnie, ale ma raczej charakter wybiórczy i punktowy. Ani nie jest powszechna, ani odgórnie forsowana. Większość porozumień, mimo doskonałych relacji politycznych na najwyższym szczeblu, jest podpisywana na szczeblu lokalnym czy samorządowym. Jako takie trudno uznać je za niosące do Polski chiński model rozwojowy czy nawet tamtejsze rozwiązania w polityce przemysłowej lub zarządzaniu. Nadal należy je uznawać za przedsięwzięcia o ograniczonym charakterze. Brakuje w naszych stosunkach dwustronnych jakiejkolwiek poważnej inwestycji (w obu kierunkach), którą można byłoby uznać za symboliczną. Natomiast rozważania o zaangażowaniu chińskiego kapitału w budowę Centralnego Portu Lotniczego ulokowanego między Warszawą a Łodzia, jak dotąd należy bardziej uznać za spekulacje medialne niż realne porozumienia.

Jednakże najważniejszym, niezbywalnym atutem w stosunkach dwustronnych Polski z Chinami jest fakt, że strona chińska wyszła z dwoma śmiałymi projektami, najpierw współpracy z państwami naszego regionu w formule 16+1, a następnie w ramach wizji BRI. Chociaż nie wiadomo jak dalej potoczą się losy oby tych projektów i czy - z chińskiej woli - nie dojdzie pomiędzy nimi do fuzji, to jednak wszystko wskazuje na to, że zainteresowanie Chin Europą i UE, w tym Polską pozostanie trwałe, a nawet może się zwiększyć z racji ostatnich amerykańskich wizji izolacjonistycznych oraz widma wojny handlowej. 
Ten ostatni czynnik, ze względu na specyfikę polskich relacji i sojusz z USA, nie ułatwi zapewne stosunków z nowym graczem w naszym regionie, jakim stały się Chiny, ale z całą pewnością zmusza do podejmowania bardziej kreatywnego i strategicznego w wymiarze myślenia także w Warszawie.

Strona chińska bezustannie podkreśla, że BRI ma jak najbardziej otwarty charakter, praktycznie może do tego projektu przystąpić każdy, kto chce. Natomiast Polska nie tylko może, ale powinna do niego przystąpić z trzech podstawowych powodów: 1) lokalizacji; 2) płynących z punktu (1) chińskich interesów związanych z naszym krajem; 3) największego w regionie EŚSW potencjału. Jednakże stopień tego zaangażowania powinien być stale starannie mierzony i dozowany, albowiem mamy do czynienia z niesymetrycznością potencjałów i mocy. Chiny to nowy globalny gracz ze swoimi interesami, a Polska jest - i powinna być - ulokowana na Zachodzie, tak pod względem bezpieczeństwa (NATO), jak i w sferze gospodarczej (UE, Niemcy), chociaż w tej drugiej właśnie BRI dowodzi, jak ważnym graczem w praktycznie wszystkich obszarach na świecie, włącznie z naszym regionem $(16+1)$ stały się Chiny. Najwyższy czas, by wyciągnąć stąd w Warszawie należyte wnioski.

\subsection{Potencjalne rodzaje ryzyka}

Podstawowy problem Polski i innych krajów regionu EŚW w stosunkach z Chinami są niesymetryczne relacje. Mamy do czynienia z partnerem wyrastającym na nowe supermocarstwo, drugą gospodarką świata (pierwszą w sensie siły nabywczej pieniądza) i państwem po 2012 r. z otwartą przyłbicą głoszącym, że zamierza być numerem jeden na świecie, nie tylko w wymiarze gospodarczym czy handlowym. Tym samym stosunki z tym partnerem mają charakter geostrategiczny i wymagają głębokiego, strategicznego namysłu.

Polska jest i pozostanie członkiem sojuszy zachodnich (NATO) i, podobnie jak państwa regionu, jest gospodarczo uzależniona od rynków UE oraz przede wszystkim od Niemiec. Tym samym ściślejsze stosunki z Chinami mogą budzić podejrzenia naszych sojuszników, począwszy od USA, jak też naszych partnerów handlowych, począwszy od Niemiec. Trzeba te czynniki brać pod uwagę we wszystkich porozumieniach i kontaktach z Państwem Środka. Tak po prostu dyktują prawa strategii i geostrategii.

Chińskie inicjatywy $16+1$, a następnie BRI sprawiły, że mimo woli Polska i nasz region weszły do wielkiej gry, albowiem Chińczycy nie tylko pojawili się na naszych rynkach, ale mają też tutaj swoje interesy i pola oddziaływania. Tymczasem - przykładowo - mocno forsowane przez Chiny projekty infrastrukturalne w wielu przypadkach stoją $\mathrm{w}$ sprzeczności z forsowaną przez UE siecią 
TENT (Tran-European Transport Network), co raz jeszcze dowodzi kontrowersji związanych $\mathrm{z}$ ewentualnymi porozumieniami ze stroną chińską. W przypadku Polski wymaga to namysłu i zastanowienia czy opowiadamy się za unijnym projektem korytarza Bałtyk - Adriatyk i czy chcemy szukać synergii między projektem forsowanym przez polskie władze, a szczególnie prezydenta, by budować Trójmorze a podobnymi propozycjami chińskimi, mającymi na celu łączenie morskiego i lądowego Jedwabnego Szlaku. Można te inicjatywy traktować rozłącznie, a można też próbować je łączyć: wybór należy do nas.

$\mathrm{Z}$ kolei w wymiarze czysto ekonomicznym największym naszym problemem jest chroniczny deficyt państw naszego regionu z Chinami, a inicjatywy $16+1$ oraz BRI niewiele pod tym względem zmieniły, Według danych chińskich, w okresie 2010-2016 chiński eksport do regionu EŚW wzrósł o 22,74\%, z 53,09 do 65,17 mld dolarów, natomiast import wzrósł co prawda w tym czasie o 41\%, ale zamyka się o wiele mniejszymi sumami - z 6,89 do 9,72 mld dolarów. Ponadto obroty te w ostatnich latach stanowią jedynie ok. 10\% obrotów handlowych całej UE z Chinami, a ujemne saldo w handlu zwiększyło się w tym czasie z 46,2 do 55,45 mld dolarów (Deng Jing i Liu Xiaojing, 2018, s. 2, 3). Sprawa jest na tyle poważna, że trafiła do dokumentu końcowego po ostatnim szczycie 16+1 w Sofii (Szczudlik-Tatar, 2018).

Deficyt ten jest również podstawową bolączką w kontaktach Polski z Chinami. W okresie 2009-2017 wzrósł ponad dwukrotnie, z 9 do 14,5 ml dolarów i w ten sposób przykrył niewątpliwy sukces Polski, jakim był najwyższy w historii eksport polskich towarów do Państwa Środka w 2017 r. w wysokości 3,35 mld dolarów, zwiększając się ponad trzykrotnie w stosunku do poziomu sprzed uruchomienia formuły 16+1. Według danych Głównego Urzędu Celnego ChRL, nie do końca zbieżnych z podawanymi przez polski GUS, dwustronne obroty handlowe zwiększyły się w okresie 2012-2017 z 12,3 do - po raz pierwszy historii - poziomu ponad 20 mld dolarów według danych chińskich (17,85 według GUS $)^{14}$.

Niejednoznaczność w statystykach dotyczących handlu z Chinami polega na tym, że poważna jego część idzie przez Hongkong oraz raje podatkowe typu Kajmany czy Wyspy Dziewicze. Tym samym trudniej o zdobycie jednorodnych i bardziej precyzyjnych danych. natomiast podstawowy problem, jakim jest poważny deficyt w handlu, w naturalny sposób kładzie się wielkim cieniem na całości naszych dwustronnych stosunków. Według obliczeń jednego chińskich autorów, skumulowany deficyt Polski w handlu z ChRL w okresie 2008-2016 wyniósł 154,4 mld dolarów(Lin Yue, 2018, s. 9).

14 https://www.bankier.pl/wiadomosc/Eksport-z-Polski-do-Chin-najwyzszy-w-historii-7568470.html (dostęp: 16.07.2018). 
Taki stan rzeczy niepokoi, bo musi niepokoić. Tym bardziej, że w chińskiej ofercie towarowej jest coraz więcej towarów wysoko przetworzonych, w tym wysokich technologii, podczas gdy w naszej dominują surowce lub towary nieprzetworzone, dopiero w ostatnim czasie uzupełnione o chemikalia czy wyroby farmaceutyczne. Tak oto kraj, któremu UE (wraz z USA) nie chce nadać statusu gospodarki rynkowej oraz mianowany „państwem rozwijającym się” eksportuje towary wyższej jakości do obszaru formalnie należącego do UE, a więc jednego z najbardziej rozwiniętych na świecie.

To nie jedyny paradoks dowodzący tego, by jak najszybciej przewartościować swoje podejście do Chin. Tymczasem, jak już wspomniano, jedynie Węgry mają w regionie wypracowaną strategię współpracy z Chinami i polityczną wolę jej kontynuacji, natomiast jedynie Słowacja - kraj o słabo rozwiniętej skali współpracy z Chinami - wypracowała specjalny Plan Akcji na okres 2017-2020, uzupełniony o rządową Koncepcję rozwoju relacji gospodarczych z ChRL (Kironská i Turcsányi, 2017, s. 9). Podczas gdy takie dokumenty na pewno przydałyby się we wszystkich państwach EŚW.

W Polsce regularne analizy na temat Chin na szczeblu centralnym prowadzą, na dobrym poziomie, ale w daleko niewystarczającym stopniu, zaledwie dwa ośrodki: Polski Instytut Spraw Międzynarodowych (PISM) oraz Ośrodek Studiów Wschodnich (OSW). Pierwszy skoncentrowany jest na badaniu całości polityki zagranicznej państwa, w ramach której podejście do Chin czy wschodzących rynków odgrywa jedynie marginalną rolę (zaledwie dwójka analityków zajmujących się wyłącznie Chinami), a drugi skoncentrowany jest o wiele bardziej na obszarach poradzieckich, aniżeli regionie Azji Wschodniej. Tymczasem to ten ostatni - obok Chin i Tajwanu także obie Koree czy Japonia - odgrywa coraz większą rolę na arenie międzynarodowej, już nie tylko w wymiarze gospodarczo-handlowym, lecz także jak najbardziej strategicznym. Warto byłoby z tego wyciągnąć należyte wnioski i jak najszybciej utworzyć specjalny zespół czy nawet instytut analityczny zajmujący się wyłącznie tym obszarem i jego znaczeniem, co byłoby zapewne spełnieniem dobrze rozumianych interesów naszego kraju.

\section{Podsumowanie}

Tak zwana piąta generacja przywódców ChRL z Xi Jinpingiem na czele, u władzy od końca 2012 r., zerwała z poprzednią polityką skromności i (od) budowy własnej potęgi po cichu, bez zwracania uwagi świata zewnętrznego, jak postulował w swym politycznym testamencie wizjoner najpierw prorynkowych 
reform (1978), a potem włączenia Chin w globalizację (1992) Deng Xiaoping. Nowa ekipa wyszła $z$ bardzo śmiałymi projektami tak na scenie wewnętrznej („dwa cele na stulecie”), jak i międzynarodowej, w postaci OBOR - BRI. Od tej chwili należy traktować relacje z Chinami jako nowo wyłaniającym się mocarstwem, mającym wpływ na układ sił na świecie, poprzez swoją wagę i rangę przywracającym nowy multipolarny ład światowy, z Chinami mającymi coraz więcej do powiedzenia w wielu dziedzinach, także w sferze modeli rozwojowych, o czym traktuje ten tom, a czemu - jak wykazuje niniejsza analiza - strona polska najwyraźniej nie przypisuje należytej wagi.

Poprzedzająca wizję BRI koncepcja 16+1 z 2012 r. jest dobrą platformą współpracy Chin z danym regionem, chociaż od początku budziła podejrzenia czy kontrowersje o stosowanie przez Chiny zasady „dziel i rządź” czy to w USA, czy instytucjach unijnych oraz najważniejszych stolicach państw UE, począwszy od Berlina, jako że - jak wykazują dostępne statystyki i dane - cały region EŚW jest mocno gospodarczo i handlowo uzależniony od Niemiec. Ten czynnik trzeba stale uwzględniać w polskich kalkulacjach, mając na uwadze jakikolwiek rozwój stosunków z Chinami, partnerem pożądanym, bo mającym u nas swoje interesy, a na dodatek bogate zasoby kapitałowe i własne projekty oraz propozycje.

Właśnie uwarunkowania zewnętrzne sprawiają, iż w żadnej mierze nie dziwi fakt, że z chwilą wprowadzenia nowej dynamiki, a raczej turbulencji do stosunków tak z Chinami, jak i z UE przez nową administrację amerykańską Donalda Trumpa, u władzy od stycznia 2017, już nie tylko niektóre państwa 16 (jak Estonia, Litwa czy Albania) zaczęły się wahać co do swego dalszego udziału w tym formacie, ale zaczęli się zastanawiać nad sensem jego dalszego funkcjonowania w tej formule sami pomysłodawcy, czyli Chińczycy, o czym świadczą - nigdy oficjalnie nie potwierdzone, ale też nie zanegowane przez Pekin - koncepcje a to urządzania szczytów $16+1$ nie raz do roku, lecz raz na dwa lata (następny zapowiedziano w Chorwacji, ale bez daty), a to włączenia do nich najbardziej „drażliwych” Niemiec. Coraz więcej sygnałów napływających z Chin wskazuje również na to, iż formuła $16+1$ stanie się integralną częścią BRI.

Stanie się tak przede wszystkim dlatego, że w odpowiedzi na amerykańskie koncepcje unilateralizmu, protekcjonizmu, a nawet wojny handlowej w wykonaniu administracji Donalda Trumpa, strona chińska coraz mocniej forsuje własne, czyli wsparcie globalizacji oraz zasad wolnego handlu i reguł obowiązujących w WTO. Co więcej, przywódcy chińscy, w opozycji do projektu America First, zaczynają promować koncepcję community of shared destiny, a więc opartej na płynącej z sił globalizacji wspólnocie interesów, gdzie na dodatek ma dominować - według Pekinu - zasada obopólnych korzyści (win-win), co jednak nie wszyscy partnerzy Chin przyjmują jako dobrą monetę. 
Takie podejście Chin oraz ich rosnący potencjał, także inwestycyjny (od 2014 r. inwestycje z Chin wychodzące są większe od tych, które do nich przychodzą) sprawiają, że dosłownie każde państwo na świecie powinno przeprowadzić swoisty rachunek sumienia w stosunkach z tym nowym kolosem. Jak najbardziej dotyczy to także Polski, najważniejszego państwa w regionie EŚW, na dodatek położonego na głównej trasie lądowego Jedwabnego Szlaku rysowanego przez Chiny. Obok, zainicjowanych przez stronę polską, transportów kolejowych między oboma krajami, są to dwa niezbywalne atuty naszego kraju w stosunkach z Chinami, które na dodatek, kierując się oczywiście własnymi interesami, nie tylko chcą przyjść do Polski, ale rzeczywiście przychodzą - jako inwestor i nowy gracz.

Niestety, jak dowodzi niniejsza analiza, bardzo dobra sieć relacji na najwyższym szczeblu politycznym w tym wizyty prezydentów obu krajów nawzajem u siebie, nie zostały, jak dotąd, przekute w prawdziwy sukces gospodarczy, a Polska nadal zmaga się z chronicznym deficytem w handlu z tym partnerem, natomiast nowe porozumienia i umowy podpisuje bardziej na szczeblu lokalnym niż ogólnokrajowym. Aktualne władze w Polsce po pierwszym zachwycie w relacjach z nowym mocarzem najwyraźniej spowolniły współpracę z Chinami, co należy rozumieć częściowo jako odpowiedź na zupełnie nową dynamikę stosunków w trójkącie USA - UE - Chiny. Podobnie jak nieobojętne oczywiście dla kształtu naszych dwustronnych relacji są - bardzo ścisłe jak dotąd - powiązania i współpraca Chin z Rosją, traktowaną w Warszawie jako nasz największy antagonista.

Nie zmienia to jednak faktu, że zakrojona na wielką skalę koncepcja BRI jest i będzie przez Pekin forsowana, a Polska jest w tamtejszych kalkulacjach brana pod uwagę jako ważny partner. Warto byłoby te nasze atuty właściwie wykorzystać. Do czego jednak niezbędna jest zarówno polityczna wola, jak i szersze zaplecze eksperckie decydentów, zdolne do wypracowania - wręcz niezbędnej w obecnych okolicznościach - strategii stosunków z Chinami. Taki potencjał w sensie osobowym posiadamy. Potrzebna jest tylko wyobraźnia i polityczna wola, by go wykorzystać.

\section{Bibliografia}

Allison, G. (2017). Destined for War. Can America and China Escape Thucidydes Trap? New York: Houghton Mifflin Harcourt.

Bartosiak, J. (2016). Pacyfik i Eurazja. O wojnie. Warszawa: Wydawnictwo CSPA. 
Chen Xin. (red.). (2017). How Hungary Perceives Belt \& Road Initiative and China-CEEC Cooperation. Beijing: China Social Sciences Press/CASS.

Czerep, J. (2017). Influence of the Lódź-Chengdu railway on the perception of $16+1$ in Poland. China - CEE Institute Working Paper, No. 5, Budapest, 15 listopada.

Deng Jing i Liu Xiaojing, (2018). Deepening the "16+1 cooperation" relationship to foster the new growth pole of Sino-EU Trade. China - CEE Institute Working Paper, No. 13, 22 czerwca.

Deng Jing i Liu Xiaojing. (2018). Deepening the "16+1 cooperation" relationship to foster the new growth pole of Sino-EU Trade. China - CEE Institute Working Paper, No. 13, 22 czerwca.

EEAS. (2016). EU - China 2020. Strategic Agenda for Cooperation. Pozyskano z: https:// eeas.europa.eu /sites/eeas/files/20131123.pdf.

Godemont, F. i Vasselier, A. (2017). China At the Gate. Anew Power Audit of EU - China Relations. ECFR, grudzień. Pozyskano z: https://www.ecfr.eu/page/-/China_Power_Audit. pdf.

Góralczyk, B. (2017). China's interest in Central and Eastern Europe: enter the dragon. European View, 16, czerwiec.

Góralczyk, B. (2017). Wschodnioazjatycki model rozwojowy - państwo rozwojowe. W: J. Yifu Lin, A.Z. Nowak (red.), Nowa Ekonomia Strukturalna wobec krajów mniej zaawansowanych. Warszawa: Wydawnictwo Wydziału Zarządzania UW.

Góralczyk, B. (2018). Wielki Renesans. Chińska transformacja i jej konsekwencje. Warszawa: Wydawnictwo Naukowe Dialog.

Góralczyk, B. (red.). (2009). Polska - Chiny: wczoraj, dziś, jutro. Toruń: Wydawnictwo A. Marszałek.

https://cen.acs.org/business/petrochemicals/BASF-considering-10-billion-investment/96/ web/2018/07 (16.07.2018).

https://global.handelsblatt.com/politics/eu-ambassadors-beijing-china-silk-road-912258 (20.07.2018).

https://www.bankier.pl/wiadomosc/Eksport-z-Polski-do-Chin-najwyzszy-w-historii-7568470. html (16.07.2018).

https://www.project-syndicate.org/bigpicture/trump-s-trade-war-expands (16.07.2018).

https://www.project-syndicate.org/bigpicture/trump-s-trade-war-expands (16.07.2018).

Huang Pingci Liu Zuokui. (red.). (2017). China - CEEC cooperation and the 'Belt and Road Initiative'. Beijing: China Social Sciences Press/CASS.

Jakóbowski, J., Popławski, K. i Kaczmarski M. (2018). Kolejowy Jedwabny Szlak. Połączenia kolejowe UE - Chiny: uwarunkowania, aktorzy, interesy. Prace $O S W, 72$, Warszawa, luty.

Joić, S. (2017). How Serbia perceives „The Belt and the Road” Initiative and 16+1 Cooperatio. China - CEE Institute Working Paper, No. 9. Budapest, 15 listopada.

Kironská, K. i Turcsányi, R.Q. (2017). Slovak Policy towards China in the age of Belt and Road Initiative and 16+1 Format. China - CEE Institute Working Paper, No. 2. Budapest, 15 listopada.

Lin Yue. (2018). Economic 'highway' with three speed tracks and destinations between China and CEE. China - CEE Institute Working Paper, No. 14, Budapest, 22 czerwca.

Liu Zuokui. (2017). Europe and the "Belt and Road" Initiative: Responses and risks. Beijing: Paths International Ltd./China Social Sciences Press/CASS.

Maddison, A. (2007). Chinese Economic Performance in the Long Run (2nd edition). OECD, Paris: Development Centre Studies. 
MERICS i Rhodium Group. (2017). Chinese Investment in Europe: record flows and growing imbalances. Joint report by MERICS and Rhodium Group. Berlin: MERICS - Mercator Institute for China Studies, styczeń. Pozyskano z: https://www.merics.org/en/papers-on-china/chinese-investment-europe-record-flows-and-growing-imbalances (15.07.2018).

Oehler-Sincai, I.M. (2018). 16+1, a New Issue in China-EU Relations? China - CEE Institute Working Paper, No 1. Budapest, 22 czerwca.

Pillsbury, M. (2016). The Hundred-year Marathon. China's strategy to replace America as the global superpower. New York: St. Martin's Griffin.

Sarek, Ł. (2017). Chiński dylemat polskiej polityki zagranicznej. Polski Przeglad Dyplomatyczny „Chiński Dylemat”, 3(70), lipiec-wrzesień.

Stanzel, A., Kratz, A., Szczudlik, J. i Pavlićević, D. (2016). China's investment in influence: the future of 16+1 cooperation. ECFR, grudzień.

Szczudlik-Tatar, J. (2018). Perspektywy format Europa Środkowa - Chiny po szczycie w Sofii. Biuletyn PISM, 91, 13 lipca.

Winter, T. (2016). One Belt, One Road, One Heritage: Cultural Diplomacy and the Silk Road. The Diplomat, 29 marca.

Xi Jinping (2014). The Governance of China. Mainland China: Foreign Languages Press.

Xi Jinping (2018). President Xi Addresses the 2018 Boao Forum for Asia in Hainan, Boa., 11 kwietnia. Pozyskano z: https://www.uscnpm.org/blog/2018/04/11/transcript-presidentxi-addresses-2018-boao-forum-asia-hainan/ (15.07.2018).

Xin Zhang. (2016). Chinese Capitalism and the New Silk Roads. Aspen Quarterly, 4.

Xinhua. (2016). China, Poland lift ties to comprehensive strategic partnership. Pozyskano z: http://www.xinhuanet.com/english/2016-06/21/c_135452132.htm (16.07.2018).

Xinhua. (2017). Xi Jinping's keynote speech at the World Economic Forum. Davos, 27 stycznia. Pozyskano z: http://www.china.org.cn/node_7247529/content_40569136.htm.

Zou Lu. (2018). An Analysis of Germany's Suspicions about „16+1 Cooperation” and China's Possible Countermeasures - From the Perspective of European Integration. China - CEE Institute Working Paper, No. 5. Budapest 22 czerwca. 
